\title{
ANALISIS KELAYAKAN USAHATANI JAMUR TIRAM PUTIH (Studi Kasus Pada Petani Jamur Tiram Bapak Baban Desa Margaluyu Kecamatan Cikoneng Kabupaten Ciamis)
}

\author{
USAHATANI FEASIBILITY ANALYSIS WHITE OTHER MUSHROOMS \\ (A Case Study of Oyster Mushroom Farmer, Mr. Baban, Margaluyu Village, Cikoneng \\ District, Ciamis Regency)
}

\author{
MOCHAMMAD IKHSAN ZARKASYIE ${ }^{1}$, IWAN SETIAWAN ${ }^{2}$, \\ MUHAMAD NURDIN YUSUF ${ }^{1}$ \\ ${ }^{1}$ Fakultas Pertanian, Universitas Galuh Ciamis \\ 2 Fakultas Pertanian Universitas Padjajaran \\ *E-mail : sanikhsan374@gmail.com
}

\begin{abstract}
ABSTRAK
Penelitian ini bertujuan untuk : 1) Mengetahui Besarnya Biaya Usahatani, 2) Penerimaan dan Pendapatan, 3) Mengetahui Kelayakan usahatani jamur tiram putih di Desa Margaluyu Kecamatan Cikoneng Kabaupaten Ciamis. Penelitian ini dilakukan mulai Januari hingga Juni 2020. Metode yang digunakan adalah metode studi kasus pada seorang petani jamur. Hasil penelitian mendapatkan hasil yang optimal setelah melakukan penelitian tentang pengalaman selama bertani. Biaya Jamur tiram putih memerlukan biaya produksi Rp10.692.975,70, - setiap siklus produksi. Penghasilan bersih berasal dari Pengolahan jamur tiram putih Rp 6.407.024,30, - setiap siklus produksi dan pendapatan kotor Rp17.100.000,00, - setiap siklus produksi. Hasil analisis yang diperoleh nilai R/C sebesar 1,60. setiap biaya yang dikeluarkan sebesar Rp 1 memperoleh penerimaan sebesar Rp 1,60, dan pendapatan sebesar Rp 0,60 sehingga usahatani layak untuk diusahakan.dan menguntungkan. Tahapan pemasarannya ada dua saluran pemasaran, yaitu saluran I (petani ke konsumen) dan saluran 2 (petani ke pedagang ke konsumen).
\end{abstract}

Kata Kunci: Biaya, penerimaan, pendapatan dan Kelayakan

\begin{abstract}
This Research aims to : 1) Knowing the Amount of Farming Costs, 2) Revenue and income 3) Knowing the feasibility of white oyster mushroom farming. in Margaluyu Village, Cikoneng District, Ciamis Regency. This research was conducted from January to June 2020. The method used was a case study method on a mushroom farmer. Research results get optimal results after conducting research on experiences during farming. The cost of white oyster mushrooms requires a production cost of IDR 10,692,975.70 per production cycle. Net income comes from processing white oyster mushrooms, Rp. 6,407,024.30, - for each production cycle and the gross income is $R p$. 17,100,000.00, - for each production cycle. The results of the analysis obtained the $R / C$ value of 1.60. Every expense incurred is Rp. 1, obtaining revenue of Rp. 1.60, and income of Rp. 0.60 so that the farming is feasible and profitable. There are two marketing channels in the marketing stages, namely channel I (farmer to consumer) and channel 2 (farmer to trader to consumer).
\end{abstract}

Keywords: Cost, revenue, income and eligibility

\section{PENDAHULUAN}

Indonesia merupakan negara agraris

yang kaya akan hasil pertanian, kehutanan, perkebunan, peternakan, dan perikanan.

Hal itu, berkaitan dengan agribisnis.

Agribisnis merupakan usaha-usaha yang 
bergerak dibidang pertanian, sehingga perlu dilakukan pengembangan usaha agribisnis dan menjadi pilihan yang sangat strategis dan penting. Sejalan dengan upaya pemerintah dalam mengembangkan sumber pertumbuhan ekonomi baru di luar minyak dan gas, salah satu bidang agribisnis pertaian yang banyak diminati masyarakat adalah bentuk usahatani budidaya jamur tiram.

Jamur tiram merupakan salah satu produk sayuran yang mudah dibudidayakan dan dikembangkan serta membutuhkan lahan yang tidak terlalu luas, relatif mudah karena menggunakan bahan-bahan seperti serbuk gergaji dan tepung jagung yang banyak terdapat di sekitar masyarakat (Rasyid, 2012).

Salah satunya produk sayuran yang dapat dikembangkan dan diarahkan untuk meningkatkan pendapatan masyarakat dan perbaiki keadaan gizi, Jamur tiram memiliki kandungan gizi lebih bagus dibandingkan dengan jenis jamur lainnya maupun sumber gizi pangan hewani (Direktorat Jenderal Hortikultutra 2006).

Salah satu daerah yang membuka peluang usahatani adalah Desa Margaluyu Kecamatan Cikoneng dengan prospek yang cukup menjanjikan ini mendorong pemilik usaha untuk menangkap peluang usaha jamur tiram putih tersebut. Usaha ini sudah berjalan selama 18 tahun produksi untuk itu perlu dilakukan analisis kelayakan usaha sehingga dapat diketahui kelayakan usaha budidaya jamur tiram.

Kecamatan Cikoneng merupakan salah satu Kecamatan yang mengembangkan jamur tiram di Kabupaten Ciamis. Dari usaha budidaya tersebut bisa membantu pertumbuhan ekonomi masyarakat sekitar. Disamping harganya relatif murah juga diminati masyarakat banyak, sehingga konsumsi masyarakat terhadap sayuran jamur tiram semakin meningkat.

Kecamatan Cikoneng memiliki 6 desa yang berfungsi sebagai sentra produksi jamur tiram putih. Khususnya di Desa Margaluyu terdapat unit usaha mikro jamur tiram putih. Tentunya setiap usahatani membutuhkan pengorbanan modal yang diinvestasikan dalam usaha tersebut.

Bedasarkan hal tersebut, biaya produksi yang dikeluarkan termasuk biaya tidak tetap, Baglog merupakan media tumbuh, campuran serbuk gergaji, dedak, dolomit, tepung jagung yang di proses sehingga menjadi media tempat tumbuhnya jamur tiram putih. Biaya tidak tetap (variable cost) yang dikeluarkan untuk pembuatan baglog.

jumlah biaya variabel untuk pembuatan 5.000 baglog sebesar Rp 5.572.000 dimana 
variabel adalah biaya tenaga kerja yang mencapai nilai sebesar $\mathrm{Rp}$ 1.120.000. Tenaga kerja untuk pembuatan baglog ini dihitung secara borongan, mulai dari pengadukan bahan baku hingga baglog tersusun dirak tempat inkubasi atau penumbuhan misselium. Setiap baglog yang dihasilkan diberi upah sebesar $\mathrm{Rp}$ 224 Sehingga untuk mendapatkan 5.000 baglog Bapak Baban harus mengeluarkan biaya tenaga kerja sebesar Rp 1.120.000.

Oleh sebab itu, perlu dilakukan analisis kelayakan usaha, jangan sampai usaha tersebut putus sebelum memberikan keuntungan.

\section{Identifikasi Masalah}

Identifikasi masalah sebagai berikut :

1. Berapa besarnya biaya usahatani ?

2. Berapa besar penerimaan dan pendapatan usahatani tersebut?

3. Bagaimana kelayakan usahatani?

\section{Tujuan penelitian}

Sesuai dengan identifikasi masalah di atas, maka tujuan penelitian ini adalah untuk mengetahui :

1. Besarnya biaya usahatani jamur tiram.

2. Besarnya penerimaan dan pendapatan usahatani.

3. Kelayakan usahatani

\section{METODE PENELITIAN}

Penelitian ini dilaksanakan menggunakan metode studi kasus pada seorang petani. Metode penelitian menggunakan penelitian kuantitatif.

Pengumpulan data dilakukan menggunakan Kuesioner, selain itu digunakan juga metode wawancara.

\section{Rencana Analisis Data}

1. Biaya Usahatani

Biaya adalah keseluruhan biaya yang dikeluarkan pada saat produksi. Biaya tetap dan biaya variabel, sehingga dapat di formulasikan sebagai berikut (Abdul, dkk., 2012) :

$\mathrm{TC}=\mathrm{FC}+\mathrm{VC}$

Keterangan:

$\mathrm{TC}=$ Total Cost (Total Biaya)

$\mathrm{FC}=$ (Total Biaya tetap)

$\mathrm{VC}=$ Total Cost $($ Total Biaya Variabel $)$

\section{Penerimaan}

Penerimaan merupakan besar pemasukan petani jamur tiram yang di peroleh dari mengalikan antara hasil panen dengan harga harga jamur tiram (Adhiyana et al, 2016) :

$\mathrm{TR}=\mathrm{Y} . \mathrm{Py}$

Keterangan:

$\mathrm{TR}=$ Total Revenue $\quad$ (Total Penerimaan) 


$$
\begin{aligned}
& \text { Y }=\text { Jumlah Produksi Jamur Tiram } \\
& \text { Py }=\text { Harga Jamur Tiram }
\end{aligned}
$$

\section{Pendapatan}

Dimana selisih antara total penerimaan dengan total biaya eksplisit yang dikeluarkan selama satu kali masa produksi (Saputra et al., 2015). Secara matematis pendapatan usahatani dapat di tulis sebagai berikut:

$$
\begin{aligned}
& \mathrm{Pd}=\mathrm{TR}+\mathrm{TC} \\
& \text { Keterangan } \\
& \mathrm{Pd} \quad=\text { Pendapatan }(\mathrm{Rp}) \\
& \mathrm{TR}=\text { Total Revenue (Total Penerimaan) } \\
& \mathrm{TC}=\text { Total Cost (Total Biaya) }
\end{aligned}
$$

\section{4. $\mathrm{R} / \mathrm{C}$}

Untuk mengetahui rasio penerimaan dan biaya usahatani jamur tiram putih digunakan perbandingan anatar penerimaan dengan biaya atau $\mathrm{R} / \mathrm{C}$ dengan rumus menurut Rahim (2007) sebagai berikut:

$$
\mathrm{R} / \mathrm{C}=\mathrm{TR} \mathrm{TC}
$$

Keterangan:

$\mathrm{R}=$ Revenue (Penerimaan)
$\mathrm{C}=$ Cost (Biaya)

Ketentuan:

a. R/C lebih besar dari 1 maka usaha menguntungkan.

b. R/C sama dengan 1 maka usaha tidak untung tidak rugi (impas).

c. R/C kurang dari 1 maka usaha jamur tiram rugi.

\section{Tempat dan Waktu Penelitian}

Penelitian ini dilaksanakan pada petani jamur di Cikoneng Kabupaten Ciamis.

\section{HASIL DAN PEMBAHASAN \\ Identitas Informan}

Respondennya adalah seorang petani jamur tiram yang berada di Desa Margaluyu. Dijalankan oleh bapak Baban, sebagai pemilik jamur tiram. Yang memulai produksinya dari mulai pembelian bahan untuk pembuatan jamur tiram putih.

Pembahasan mengenai identitas responden dijelaskan oleh beberapa aspek yaitu umur responden, tingkat pendidikan, pengalaman berusaha, serta tanggungan keluarga.

\section{Penggunaan Tenaga Kerja}

\begin{tabular}{rlccr}
\hline No & Jenis Pekerjaan & $\begin{array}{c}\text { Jumlah } \\
\text { Pekerja }\end{array}$ & $\begin{array}{c}\text { Harga } \\
\text { Satuan/Hari }\end{array}$ & Jumlah/Minggu \\
\hline 1 & Pengolahan Media & 1 & 40.000 & 280.000 \\
& Tanam & 1 & & \\
2 & Penanaman & 1 & 40.000 & 280.000 \\
3 & Sterilisasi & 1 & 40.000 & 280.000 \\
4 & Penyiraman & & 40.000 & 280.000 \\
\hline & Jumlah & & $\mathbf{1 . 1 2 0 . 0 0 0}$ \\
\hline
\end{tabular}


Menunjukan bahwa dalam tahap penggunaan tenaga kerja bukan hanya pemilik jamur tiram yang mengelola sendiri dalam media jamur tiram, juga di bantu oleh pegawai lain yang sekaligus nantinya lebih mudah dalam tahap pembuatan jamur tiram dari mulai pengelolaan media tanam sampai penyiraman dilakukan oleh petani itu sendiri.

\section{Pemasaran Baglog}

Harga jualnya sangat bervariasi berdasarkan jumlah pembelian. Dengan kata lain, ada dua variasi harga yang berlaku. yaitu harga partai (borongan) dan harga satuan (eceran). Namun pada dasarnya harga jualnya mengacu kepada harga jual pokok, harga partai digunakan sebagai bentuk diskon atau potongan harga karena membeli dalam jumlah banyak.

\begin{tabular}{|c|c|c|c|}
\hline No & $\begin{array}{c}\text { Sistem } \\
\text { Pembelian }\end{array}$ & $\begin{array}{c}\text { Harga } \\
\text { (Rp.) }\end{array}$ & Keterangan \\
\hline 1 & $\begin{array}{l}\text { Partai } \\
\text { (Borongan) }\end{array}$ & 2.500 & $\begin{array}{c}\text { Pembelian } \geq 5.000 \\
\text { baglog }\end{array}$ \\
\hline 2 & $\begin{array}{l}\text { Satuan } \\
\text { (Eceran) }\end{array}$ & 2.800 & $\begin{array}{c}\text { Pembelian }<5.000 \\
\text { baglog }\end{array}$ \\
\hline
\end{tabular}

\section{Pemasaran Jamur Tiram Putih Segar}

Untuk mempertahankan kesegaran jamur hingga ke tangan konsumen maka pemasarannya harus dilakukan sesegera mungkin. Jamur tiram yang dihasilkan memiliki dua saluran pemasaran.

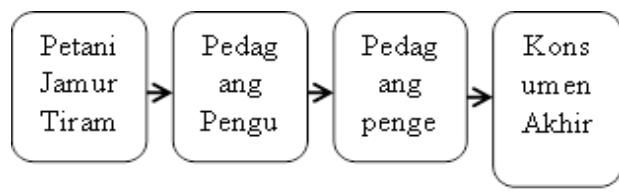

Pada saluran pertama, langsung menjual ke pedagang pengumpul dengan harga $\mathrm{Rp}$ 9.000 per kg. Pada saluran pemasaran ini, harga jual jamur tiram putih segar lebih rendah dibandingkan pada saluran pemasaran kedua.

\section{Analisis Usahatani}

Analisis usaha menggunakan biaya, pendapatan, penerimaan, dan $\mathrm{R} / \mathrm{C}$ rasio.

\section{Biaya Tetap}

Biaya yang dihitung dalam penelitian ini yaitu terdiri dari penyusutan alat, pajak bumi dan bangunan, dan bunga modal tetap. Rata-rata biaya tetap total yang dikeluarkan oleh Usahatani Jamur Tiram Putih ini adalah Rp 969.825,70,-.

\begin{tabular}{llc}
\hline No & Biaya Tetap & $\begin{array}{c}\text { Besarnya } \\
\text { Biaya (Rp) }\end{array}$ \\
\hline 1 & PBB & 4.000 \\
2 & Penyusutan & $647.031,72$ \\
& Alat & $19.016,19$ \\
\hline & Bunga Modal & $\mathbf{6 7 0 . 0 4 7 , 9 1}$ \\
\hline
\end{tabular}

Besarnya biaya dikeluarkan masingmasing responden berbeda-beda. Biaya penyusutan alat dipengaruhi oleh jenis dan banyaknya alat yang digunakan dan 
dimiliki pengrajin dalam usaha jamur tiram.

\section{Biaya Variabel}

Meliputi biaya produksi, tenaga kerja serta bunga modal variabel. Total rata-rata biaya variabel yang dikeluarkan untuk sekali proses produksi adalah sebesar Rp 9.723.150,00,--

\begin{tabular}{clr}
\hline No & Biaya Variabel & \multicolumn{1}{c}{$\begin{array}{r}\text { Besarnya Biaya } \\
\text { (Rp) }\end{array}$} \\
\hline 1 & Bibit & 1.400 .000 \\
& (Miselium) & 2.000 .000 \\
2 & Serbuk Gergaji & 2.000 .000 \\
3 & Dedak halus & 67.500 \\
4 & Kapur Dolomit & 85.000 \\
5 & Kayu Bakar & 810.000 \\
6 & Tepung Jagung & 1.950 .000 \\
7 & Plastik & 70.000 \\
8 & Karet Gelang & 30.000 \\
9 & Rapia & 1.120 .000 \\
10 & Tenaga Kerja & $\mathbf{9 . 7 2 3 . 1 5 0 , 0 0}$ \\
\hline \multicolumn{3}{c}{ Jumlah } \\
\multicolumn{3}{c}{ Dalam melakukan } \\
membutuhkan berbagai bahan baku serta \\
tenaga kerja baik.
\end{tabular}

\section{Biaya Total}

\begin{tabular}{cccc}
\hline No & $\begin{array}{c}\text { Jenis } \\
\text { Biaya }\end{array}$ & $\begin{array}{c}\text { Jumlah Biaya } \\
(\mathbf{R p})\end{array}$ & $\begin{array}{c}\text { Persentase } \\
(\boldsymbol{\%})\end{array}$ \\
\hline 1 & $\begin{array}{c}\text { Biaya } \\
\text { Tetap }\end{array}$ & $670.047,91$ & 6 \\
2 & $\begin{array}{c}\text { Biaya } \\
\text { Variabel }\end{array}$ & $9.723 .150,00$ & 94 \\
\hline & Jumlah & $\mathbf{1 0 . 3 9 3 . 1 9 7 , 9}$ & $\mathbf{1 0 0}$ \\
\hline
\end{tabular}

Berdasarkan Tabel 11, diketahui bahwa total biaya yang dikeluarkan adalah sebesar Rp 10.692.975,70.

\section{Analisis Penerimaan dan Pendapatan dan $\mathbf{R} / \mathbf{C}$}

Berdasarkan hasil penelitian diketahui bahwa produksi jamur tiram $1.800 \mathrm{~kg}$, dengan harga jual Rp 9.500 per kg.

\begin{tabular}{cccr}
\hline No & Uraian & $\begin{array}{c}\text { Satu } \\
\text { an }\end{array}$ & \multicolumn{1}{c}{ Nilai } \\
\hline 1 & Produksi & $\mathrm{Kg}$ & $1.800,00$ \\
2 & Harga Jual & $\mathrm{Rp}$ & $9.500,00$ \\
3 & Penerimaan & $\mathrm{Rp}$ & $17.100 .000,00$ \\
4 & Total Biaya & $\mathrm{Rp}$ & $10.692 .975,70$ \\
5 & Pendapatan & $\mathrm{Rp}$ & $6.407 .024,30$ \\
6 & $\mathrm{R} / \mathrm{C}$ & & 1,60 \\
\hline
\end{tabular}

Tabel 12, menunjukan bahwa total produksi yaitu Rp 9.500 per $\mathrm{kg}$. Penerimaan yang diperoleh usahatani yaitu Rp17.100.000,00 dan Pendapatan yang diperoleh Rp 10.692.975,70,

Nilai R/C yaitu 1,60 artinya setiap Rp 1 maka akan mendapatkan penerimaan sebesar Rp 1,60 dan pendapatan yang akan diterima sebesar $\mathrm{Rp}$ 0,60 maka layak di usahakan.

\section{KESIMPULAN DAN SARAN \\ Kesimpulan}

Berdasarkan hasil dan pembahasan, maka dapat ditarik beberapa kesimpulan sebagai berikut :

Biaya sebesar Rp 10.692.975,70 dan penerimaan $\operatorname{Rp} 17.100 .000,00$, pendapatan Rp 6.407.024,30.

Nilai R/C yang diperoleh yaitu 1,60, artinya setiap $\quad \mathrm{Rp} \quad 1$ memperoleh 
penerimaan sebesar $\mathrm{Rp}$ 1,60, dan pendapatan sebesar Rp 0,60 sehingga usahatani layak untuk diusahakan.

\section{Saran}

Berdasarkan kesimpulan terssebut maka disarankan hal-hal sebagai bderikut :

1) Usahatani sudah menguntungkan, maka layak untuk terus dilakukan, dengan cara produksinya lebih ditingkatkan lagi supaya keuntungan bertambah.

2) Usahatani hendaknya melakukan pengklasifikasian biaya ke dalam komponen biaya secara tepat. Dengan pengklasifikasian biaya tersebut dapat tersusun dengan baik, dengan cara membuat pencatatan biaya.

\section{DAFTAR PUSTAKA}

Agromedia. 2010 Bertanam Jamur Konsumsi. Agromedia pustaka Jakarta.

$\begin{array}{ll}\text {.2009.Bercocok Tanam Jamur } & \text { Jonsumsi. } \\ \text { PT.Agromedia.Pustaka. } & \end{array}$

Angipora, M. 2002. Dasar Dasar Pemasaran Edisi Kedua. Raja Grafindo Persada. Jakarta

Badan Pusat Statistik (BPS) Denpasar.2017. Kota Denpasar Dalam Angka 2016.

Badan Penyuluh Pertanian Kecamatan Cikoneng
Cabang Dinas Kehutanan Wilayah 7 Kabupaten Ciamis Tahun 2018.

Gittinger, JP. 2008. Analisa Ekonomi Proyek-proyek Pertanian. Edisi kedua, telah direvisi dan siperluas lengkap. Jakarta: UI-Press

Kasmir, Jakfar. 2009. Studi Kelayakan Bisnis. Ed ke-2. Jakarta: Prenada Media Group.

Mantra ida Bagus dan Kasto, 1987. Penentuan Sampel dalam Singa rimbun. Metode Penelitian Suvai LP3ES. Jakarta

Mosher, A. T, 1987. Menggerakkan dan Membangun Pertanian. Yasaguna, Jakarta.

Nazir, M. 2003. MetodePenelitian. Ghalia Indonesia. Jakarta.

Rodjak, A. 2006. Manajemen Usahatani. Pustaka Giratuna Bandung Fakultas Pertanian Univeritas Padjadjaran. Bandung.

Ruillah. Analisis Usahatani Jamur Tiram Putih (Pleurotus ostreatus) di Desa Kartawangi, Kecamatan Cisarua, Kabupaten Bandung, Propinsi Jawa Barat Bogor: IPB, Fakultas Pertanian;2006.

Saparindo, Cahyo dan sunarmi. 2010.Usahatani 6 Jenis Jamur Skala Rumah Tangga. Penebar Swadaya. Jakarta.

Suratiyah, K. 2006. Ilmu Usahatani. Penebar Swadaya. Jakarta.

Singarimbun, M dan Efendi, S. 1989. Metode Penelitian Survei. LP3ES

Soenanto, H. 2000. Jamur Tiram, Budidaya dan Peluang Usaha. Semarang : Aneka ilmu. 
Suriawiria, H.U. Budidaya Jamur Tiram. (Yogyakarta: Kanisius, 2002).

Soekartawi. 2006. Analisis Usahatani. Universitas Indonesia (UI-Press). Jakarta.

Suratiyah, K. 2006. Ilmu usahatani. Penebar Swadaya. Jakarta.

2009. Ilmu usahatani. Penebar Swadaya. Jakarta.
Tatang, N. 2015. Kiat Sukses Budidaya Jamur Tiram. YRAMA WIDYA. Bandung.

Tjaksawiralaksana. Ilmu Usahatani dan Penelitian untuk Pengembangan PetaniKecil. (Jakarta: PT Gramedia, 1983).

Umar, H. Studi Kelayakan Bisnis. (Jakarta: PT Gramedia; 1997).

Winda Andriani. 2014 Perencanaan Pemasaran Usahatani Jamur Tiram, Denpasar 